native (Peruvians have lived at about $10,000 \mathrm{ft}$. for thousands of years) would be physically superior (at altitude) to the well conditioned athlete from the lowlands. Among Leadville non-athletes, hypoventilation (shallow breathing) was common.

This seems a regular characteristic of those highland communities which have been most thoroughly studied. Dr John W. Severinghaus of the University of California San Francisco Medical Center described work on Peruvian Indians which indicated that the native who has always lived at high altitude does not breathe more deeply in a diminished oxygen atmosphere whereas a sea-level native who goes to the highlands does. Dr Severinghaus suggests that the highlander has lost sensitivity in the chemo-receptors governing this reflex. This may have very far-reaching consequences: longevity, intelligence, learning, fertility, infant survival, susceptibility to respiratory diseases may all be implicated. This reflex loss appears to tie in with the characteristic health hazard of high altitude, pulmonary oedema. This was by far the most common affliction of the several thousand Indian troops who have been stationed on the Himalayan border between 11,000 and $18,000 \mathrm{ft}$. since the 1962 emergency. Dr Inder Singh, in discussing the clinical problems encountered by the Indian forces medical services in the area, reported that diuresis induced by drugs has been found to relieve the condition.

A number of recommendations for both research projects and for practical action were adopted by the meeting. One was the preparation of a short, concise book on high altitude medicine to cover high altitude diseases, modification of common sea-level diseases at high altitude, as well as the modification of drug and anaesthetics action. It was also agreed to found a research centre of high altitude studies to act as a clearing house for information on the subject and improve scientific communication in this field.

\section{Manpower for Electronics}

A contunding shortage of scientific and technological manpower is envisaged in the electronics industry, together with a growing demand for engineering skills. These and other findings of the enquiry undertaken by the Manpower Research Unit, in association with the Electronics Economic Development Committee, are presented in Electronics-the fifth in a series of reports by the Manpower Research Unit (HMSO, 6s. $3 d$.$) . The purpose of the enquiry was to gain a$ clearer picture of likely manpower developments within the industry up to and beyond 1970, and forty-six firms participated.

According to estimates made by the Ministry of Labour, 371,000 people were employed in the electronics industry in June 1965-288,000 were in electronics and 83,000 were in telecommunications. Shortages of labour were common throughout the industry. The over-riding factor in determining the size of the labour force-not surprisingly, perhaps-was the level of demand for products. The development of microcircuits, the report says, calls for more support at technician level, while the development of printed circuits and semi-conductors would probably involve less mechanical assembly and a move from male to female assessors.

Most firms, it is reported, thought that technological change, including the use of computers for planning and managerial control, would be the principal means of increasing productivity. Incentive schemes were favoured by some firms but criticized by others and other important contributions to productivity were expected from work and methods study, training and standardization of production.

Estimates were made of changes in the occupational structure of the industry between 1965 and 1970 and an increase in the employment of scientists and technicians is expected in the fields of radio and other electronic apparatus and in telecommunications. Shortage of production engineers, systerns and circuit engineers and computer staff was particularly evident at the time of the enquiry, and it was suggested that, although in general the basic cause of shortages was the rapid expansion of the industry and the rate of technical change within the individual firm, the most important fact was the continuing transfer of scientists and technologists to managerial posts. Furthermore, the report suggests that there is a need to encourage more young people to take up science and engineering and the "one-way traffic" of graduates into the academic field is criticized.

\section{Parliament in Britain}

\section{Nuclear Ships}

MR A. WEDGwood BenN, Minister of Technology, has agreed to consider the recommendation of the Select Committee on Science and Technology that a departmental committee be convened to examine the possibilities of nuclear marine propulsion. He pointed out that the responsibility for the Atomic Energy Authority, the nuclear industry, the manufacture of marine engines and shipbuilding had all been placed on his department. It was in touch with all the interests concerned and he intended to re-examine the position to ensure, as far as possible, that Britain was in a position to embark on a major project as soon as it appeared that commercial demand for such ships justified the considerable cost involved. (Written answer, December 5.)

\section{Patents}

IN a debate in the House of Commons on November 30, Mr C. Fletcher-Cooke and Sir Lionel Heald challenged the idea that the Patent Office and the Trade Mark Registry should be self-supporting. Mr FletcherCooke maintained that Parliament had never said that they should pay their way and argued that the increase in fees proposed for filing patent applications, complete specifications, trade marks and their renewals was unjustified and constituted a discouragement to invention. Sir Lionel Heald questioned the organization and efficiency of the Patent Office. Had any real effort been made to produce a more modern and efficient system ? The Minister of State at the Board of Trade, Mr G. Darling, who replied for the Government, did not think that the increased fees would discourage applications, and pointed out that on an average the Patent Office spent $£ 55$ on each application against the $£ 15$ which would now be received and that 70 per cent of all applications came from overseas. He paid tribute to the efficiency of the Patent Office and its staff. He would be glad, he said, to see it moved from its present premises, but he did not think it should be run at a loss. (Debate, November 30 .) 